УДК 330.341.1

DOI https://doi.org/10.32851/tnv-pub.2021.3.12

\title{
ФОРМУВАННЯ ДЕРЖАВНОЇ ПОЛІТИКИ ЦИФРОВОГО РОЗВИТКУ: СУЧАСНІ ТЕНДЕНЦІЇ ТА ПЕРСПЕКТИВИ
}

\author{
Островий О.В. - кандидат наук з державного управління, докторант \\ Донецького державного університету управління \\ ORCID: 0000-0002-7704-5149
}

У статті визначено, щзо цифррові технологї створюють додаткові можливості для соціально-економічного розвитку країн світу. Акиентовано увагу на тому, щзо процеси ичфровізації пов'язані зі значною кількістю викликів $і$ проблем, які потребують своєчасного вирішення у рамках державної політики. Встановлено роль держсавного регулювання у сфері цифррових трансформачій. Автором досліджено різні підходи до визначення поняття «державна політика». Це дозволило констатувати неоднозначність його тлумачення у наукових дискурсах, проте, незважаючи на різні трактування, їх об'єднує спрямованість державної політики на вирішення конкретної проблеми на користь суспільства. Спираючись на наявний теоретичний базис, сформульовано поняття «державна політика ццифрового розвитку». Досліджено сучасні тенденції розвитку вітчизняної ццифрової економіки. Визначено особливості державного управління у цій сфері. Відзначено, щзо у рамках формування та реалізації державної політики циифрового розвитку в Україні запроваджено низку законодавчих ініціатив. Особливу увагу акцентовано на розвитку державних інституцій, котрі відповідають за управління процесами ичифровізації у державі. Зазначено, щзо врахування світових тенденцій дозволить забезпечити належний рівень иифрового розвитку у країні. Автором проаналізовано досвід формування державної політики ичировізаиї у країнах Свропейського Союзу, який становить інтерес для подальшої адаптації в Украӥні. Встановлено, ио державне регулювання у иій сфері базується переважно на економічних інструментах, максимально зменшуючи використання адміністративних методів. Спираючись на передовий закордонний досвід, нинішні изифрові тренди, враховуючи сучасні виклики та загрози, конкретизовано перспективні напрями розвитку державної політики у сфері циифрових трансформацій.

Ключові слова: державна політика, державне регулювання, цифровізація, розвиток, ичифрові трансформації.

Ostrovyj O. V. Formation of state policy for digital development: modern trends and prospects

The article determines that digital technologies create additional opportunities for the socioeconomic development of the countries of the world. Attention is focused on the fact that digitalization processes are associated with a large number of challenges and problems that require timely solutions within the framework of state policy. The role of state regulation in the field of digital transformations has been established. Various approaches to the definition of the concept of "public policy" have been investigated. This made it possible to state the ambiguity of its interpretation in scientific discourses. However, despite different interpretations, they are united by the orientation of state policy towards solving a specific problem in the interests of society. Based on the existing theoretical basis, the concept of "state policy of digital development" has been formulated. The current trends in the development of the domestic digital economy have been investigated. The features of public administration in this area have been determined. It is noted that within the framework of the formation and implementation of the state policy of digital development, a number of legislative initiatives have been proposed in Ukraine. Particular attention is focused on the development of state institutions responsible for managing digitalization processes in the state. It is indicated that taking into account the existing global trends will ensure an appropriate level of digital development of the country. The experience of the formation of the state policy of digitalization in the countries of the European Union is analyzed, which is of interest for adaptation in Ukraine. It has been established that state regulation in this area is based primarily on economic instruments, minimizing the number of administrative methods as much as possible. Based on advanced foreign experience, existing digital trends, taking into account modern challenges and threats, promising directions for the development of state policy in the field of digital transformations have been concretized.

Key words: government policy, government regulation, digitalization, development, digital transformation. 
Постановка проблеми. Сучасні цифрові технології, проникаючи у різні сфери діяльності, здійснюють значний вплив на життєдіяльність суспільства, створюючи можливості для соціально-економічного розвитку будь-якої країни світу. Вони здатні сприяти «подоланню соціальної ізоляції, підвищенню продуктивності праці, впровадженню інновацій» [1], «докорінно перетворити наше життя, забезпечуючи процвітання націй» [2], а завдяки використанню економії від масштабу та мережевих ефектів формують додаткові резерви для економічного росту країн, які розвиваються [3], однак слід констатувати, що трансформаційні процеси одночасно пов'язані зі значною кількістю викликів і проблем, які потребують своєчасного вирішення у рамках відповідної державної політики. Серед основних із них варто відзначити такі: рівень розвитку інфраструктури та доступ до необхідних даних; забезпечення кібербезпеки; формування необхідної нормативно-правової бази; стимулювання інвестиційних процесів тощо.

Провідна роль держави у процесах цифровізації та необхідність формування державної політики, яка повинна мати системний характер, доведена досвідом розвинутих країн світу, котрі пройшли значний шлях у цьому напрямі та мають напрацювання стосовно запровадження інструментів державного регулювання.

Зазначимо, що сьогодні здійснюється активне формування вітчизняної системи державного управління цифровим розвитком, що актуалізує питання дослідження їі сучасного стану та визначення перспективних напрямів (із урахуванням актуальних викликів і загроз).

Аналіз останніх досліджень і публікацій. Проблеми формування державної політики перебувають у полі зору таких дослідників, як: О. Балуєва [4], О. Берназюк [5], О. Валевський [6], Ю. Ковбасюк [7], В. Степанов [8] та ін. Процеси цифровізації й окремі аспекти їх регулювання розглядали такі вітчизняні та закордонні науковці: В. Бондарчук [9]; А. Мк. Афее, Д. Боннет [10]; Е. Бринолфссон [11]; Дж. Вестерман [10]; Д. Еванс [11]; Ю. Корнєєва [13]; К. Шиманська [9].

Однак питання формування вітчизняної державної політики цифрового розвитку (з урахуванням світових практик, сучасних викликів і загроз) потребують додаткової уваги. Це дозволить актуалізувати перспективні напрями розвитку, стимулювати відповідні трансформаційні процеси у країні.

Метою статті є дослідження сучасних тенденцій формування вітчизняної державної політики цифрового розвитку та визначення її перспективних напрямів.

Виклад основного матеріалу. Дослідження терміна «державна політика» дозволило констатувати неоднозначність його тлумачення у наукових дискурсах. Дослідники визначають це поняття, акцентуючи увагу на:

- відносній стабільності організації та цілеспрямованій діяльності державних інституцій, яка здійснюється ними безпосередньо чи опосередковано щодо певної проблеми або сукупності проблем, що впливає на життя суспільства [6, с. 32];

- сукупності ціннісних цілей, державно-управлінських заходів, рішень і дій, порядку реалізації державно-політичних рішень (поставлених державною владою цілей) і системі державного управління розвитком країни [7, с. 8];

- наборі цінностей, цілей i знарядь, пов'язаних із визначенням суспільних проблем, що вимагають уваги [11].

Незважаючи на різні підходи до трактування, їх об’єднує спрямованість державної політики на вирішення конкретної проблеми на користь суспільства. Спираючись на вищевказані поняття, вважаємо, що під державною політикою цифрового розвитку слід розуміти засновану на чинних нормативно-правових актах, узгоджену за цілями систему державно-управлінських заходів із боку 
органів державної влади, спрямовану на реалізацію функцій держави у сфері цифрових трансформацій із метою просування цифрових технологій у всі сфери суспільного життя та забезпечення належних умов і можливостей для цифровізації національного господарства, з дотриманням базових принципів і забезпеченням цифрової безпеки, цифрових прав і свобод, інтересів громадян, суспільства та держави загалом.

Як свідчать результати досліджень, державна політика цифрового розвитку країн Свропейського Союзу (СС) реалізується на основі стратегічного підходу (на національному та наднаціональному рівнях), що передбачає запровадження «цифрових адженд», спрямованих на активні цифрові трансформації та формування Сдиного цифрового ринку СС.

Слід констатувати, що характерною особливістю цифрового розвитку розвинутих країн світу $є$ міжнародне співробітництво й інтеграція, які проявляються у досягненні сумісності стандартів, протоколів та інтерфейсів. Крім того, значна увага приділяється формуванню нормативно-правової бази.

Проводячи відповідні паралелі, слід вказати, що у рамках формування та реалізації державної політики цифрового розвитку в Україні запроваджено низку законодавчих ініціатив.

Зазначимо, що фактичною дорожньою картою цифрової трансформації вітчизняної економіки є Концепція розвитку цифрової економіки та суспільства України на 2018-2020 pp.

Цим документом визначено такі цілі цифрового розвитку країни [14]:

- прискорення економічного зростання та залучення інвестицій;

- трансформацію секторів економіки у конкурентоспроможні й ефективні;

- технологічну та цифрову модернізацію промисловості та створення високотехнологічних виробництв;

- доступність для громадян переваг і можливостей цифрового світу;

- реалізацію людського ресурсу, розвиток цифрових індустрій і цифрового підприємництва.

Крім того, розвитку цифрових технологій в Україні як «основі добробуту України; світу, де створюються нові можливості» [15] приділено увагу в Національній економічній стратегії на період до 2030 р., де сформовано основні напрями розбудови ефективної цифрової сервісної держави, розвитку цифрової економіки.

Урядом також затверджено План заходів із розвитку широкосмугового доступу до Інтернету на 2021-2022 рр. Документ передбачає збільшення кількості населених пунктів із можливістю під'єднання до високошвидкісного Інтернету, що дозволить підвищити рівень цифровізації у регіонах, а мешканцям - отримувати державні послуги онлайн.

Європейські практики підтверджують значущість цифрових компетентностей населення та їхній вплив на розвиток економіки та рівень конкурентоспроможності країни й акцентують увагу на необхідності запровадження відповідного комплексу заходів щодо їх формування та вдосконалення.

Так, наприклад, Європейським Парламентом і Радою ЄС ухвалено Рамкову програму оновлених ключових компетентностей для навчання впродовж життя (2018/C 189/01), у якій цифрова компетентність визнана однією з основних для забезпечення повноцінного буття та діяльності громадян.

На вимогу часу, враховуючи євроінтеграційний курс держави, який передбачає подальшу адаптацію законодавства України до норм СС, запроваджено Концепцію розвитку цифрових компетентностей і затверджено план заходів із іiі реалізації. 
Слід звернути увагу на те, що ця Концепція спрямована на розв'язання проблем у сфері розвитку цифрових компетентностей, які пов'язані з відсутністю: відповідного правового регулювання; рамок цифрової компетентності, а також вимог до рівнів володіння цифровими навичками та цифровими компетентностями різних категорій працівників; єдиних підходів до визначення цифрових компетентностей у професійних стандартах; єдиних вимог до цифрових компетентностей у системі освіти; координації дій на рівні органів виконавчої влади й органів місцевого самоврядування під час реалізації державної політики у сфері розвитку цифрових навичок і цифрових компетентностей; системи сертифікації рівня цифрових компетентностей тощо [16].

Зауважимо, що формування та реалізація державної політики у певній сфері здійснюється відповідними міністерствами. Однією з перших країн, де розпочав свою діяльність державний інститут, відповідальний за управління процесами цифровізації, стала Велика Британія з її Міністерством цифрової економіки. Відзначимо, що саме ця країна на сучасній міжнародній арені демонструє найкращі результати розвитку у сфері інновацій та інформаційних технологій.

Констатуємо, що з метою формування та реалізації державної політики у сфері цифрового розвитку в Україні теж створено відповідну державну інституцію Міністерство цифрової трансформації, яким сьогодні визначено стратегічні кроки та сформовано низку пакетних пропозицій і проєктів розвитку вітчизняної цифрової економіки.

Результати досліджень свідчать про те, що серед інструментів державного регулювання цифрового розвитку у країнах СС обираються переважно економічні, а використання адміністративних методів зведено до мінімуму. Така політика здійснюється шляхом стимулювання інвестиційних процесів; зменшення торгівельних обмежень між країнами; створення умов для спрощення реєстрації бізнесу; зниження ліцензійних і дозвільних обмежень для розвитку електронного бізнесу тощо. Окрема увага приділяється розвитку цифрового підприємництва та міжнародного бізнесу, в тому числі на основі цифрових платформ.

На національному рівні широко запроваджуються програми, спрямовані на використання нових цифрових технологій у різних галузях економіки. Наприклад, «Industry 4.0» (Німеччина), «Фабрики Майбутнього» (країни СС) тощо. Їх фінансування здійснюється переважно з використанням механізму публічно-приватного партнерства.

Зазначимо, що дослідження сучасних тенденцій розвитку вітчизняної державної політики цифровізації дозволили виокремити низку проблем у цій сфері, які гальмують трансформаційні процеси у країні та пов'язані з: недосконалістю законодавчої бази й уповільненням розробки й адаптації законодавства до умов цифрового розвитку; недостатнім рівнем інфраструктурного розвитку й інвестиційної активності; відсутністю стратегічних документів у сфері цифрового розвитку; недостатнім рівнем цифрових навичок і цифрової культури населення; низьким рівнем державної підтримки та стимулювання цифрового розвитку.

Спираючись на передовий закордонний досвід, цифрові тренди, враховуючи сучасні виклики та загрози, вважаємо доцільним сформувати перспективні напрями розвитку державної політики у сфері цифрових трансформацій, а саме:

- подальшу розробку відповідного нормативно-правового підгрунтя, у тому числі щодо хмарних технологій, у сфері безпеки та захисту інформації;

- гармонізацію законодавчої бази із чинними міжнародними нормативно-правовими актами, у тому числі у галузі захисту інформації; 
- збільшення рівня покриття фіксованим і мобільним Інтернетом; розробку та реалізацію Стратегії розвитку широкосмугового доступу до Інтернету як документа, що визначає напрями розв'язання проблем, пов'язаних із «цифровим розривом» і забезпеченням населення доступом до мережі, документально зафіксує зобов'язання держави у цьому напрямі;

- реалізацію сучасних проєктів у сфері цифрових трансформацій, використання потенціалу концесійних моделей, залучення у ці сфери інвестицій;

- розвиток інформаційно-комунікаційних і цифрових технологій, відповідної інфраструктури (у тому числі на основі кластерів, наукових парків, промислового інжинірингу);

- стимулювання цифровізації та модернізації галузей економіки;

- запровадження комплексних підходів до здійснення цифрових трансформацій у різних сферах (освіті, медицині, управлінні містами тощо).

Висновки і перспективи подальших досліджень. Цифрові технології створюють додаткові можливості для соціально-економічного розвитку країни. Значну роль у процесах цифрових трансформацій відіграє системна державна політика. Як свідчать результати досліджень, у ії рамках в Україні запроваджено низку ініціатив, котрі враховують світові цифрові тренди та тенденції. Провідні країни світу вже мають певні напрацювання у сфері державного регулювання цифрового розвитку, віддаючи перевагу економічним інструментам і мінімізуючи використання адміністративних методів. Сучасні світові практики дозволили конкретизувати перспективні напрями розвитку вітчизняної державної політики цифровізації, але їх практична реалізація можлива за умов формування відповідних механізмів (правового, економічного, організаційного та ін.), що становить перспективи подальших досліджень.

\section{СПИСОК ВИКОРИСТАНОЇ ЛІТЕРАТУРИ:}

1. World Bank Group. World Development Report 2016: Digital Dividends. Washington, DC : World Bank, 2016. 330 p.

2. Dahlman C., Mealy S., Wermelinger M. Harnessing the digital economy for developing countries. OECD Development Centre Working Papers. OECD Publishing. Paris, 2016. № 334. 80 p.

3. World Investment Report 2017: Investment and digital economy. UNCTAD, 2017. URL: https://unctad.org/en./publicationslibrary/wier2017_en/pdf. (дата звернення 20.11.2021).

4. Балуєва О.В., Чуприна О.О. Методичні основи моделювання стратегічних пріоритетів соціально-економічного розвитку територій. Менеджер. Вісник ДонДУУ. Серія «Економіка». 2019. № 4 (85). C. 23-30. DOI: 10.35340/2308-104X. 2019.85-4-03

5. Берназюк О. Роль та місце цифрових технологій у сфері публічного управління. Інформачійне право. 2017. № 10. URL: http://pgp-journal.kiev.ua/ archive/2017/10/35.pdf (дата звернення: 17.11.2021).

6. Валевський О.Л. Державна політика в Україні: методологія аналізу, стратегія, механізми впровадження : монографія. Київ : НІСД, 2001. 242 с

7. Державна політика : підручник / Нац. акад. держ. упр. при Президентові України ; ред. кол. : Ю.В. Ковбасюк, К.О. Ващенко, Ю.П. Сурмін та ін. Київ : НАДУ, 2014. 448 с.

8. Степанов В.Ю. Сучасні інформаційні технології в державному управлінні. Економіка та держава. 2010. № 9. C. 101-105. URL: http://www.economy.in.ua/ pdf/9_2010/32.pdf (дата звернення: 01.11.2021). 
9. Шиманська К.В., Бондарчук В.В. Пріоритетні напрями та механізми розвитку цифрової економіки в Україні. Економіка, управління та адміністрування. 2021. № 1 (95). C. 17-22.

10. Westerman G., Bonnet D., McAfee A. Leading Digital: Turning Technology into Business Transformation. USA : Harvard Business School Publisher, 2014. 292 p.

11. Brynjolfsson E., Kahin B. Understanding the Digital Economy: Data, Tools, and Research [reprint]. USA : MIT Press, 2002. 407 p.

12. Evans D. The Internet of Things: How the Next Evolution of the Internet Is Changing Everything. CISCO White Paper. April 2011. URL: http://www.cisco.com/ web/about/ac79/docs/innov/IoT_IBSG_0411FINAL.pdf (дата звернення 21.10.2021).

13. Корнєєва Ю.В. Роль держави у сприянні інвестиціям у розвиток цифрової економіки. Економіка прогнозування. 2018. № 1. С. 120-134.

14. Про схвалення Концепції розвитку цифрової економіки та суспільства України на 2018-2020 роки : Розпорядження Кабінету Міністрів України від 17 січня 2018 р. № 67. Офіційний вісник Украӥни. 2018. № 16. Ст. 560.

15. Про затвердження Національної економічної стратегії на період до 2030 р. : Постанова від 03 березня 2021 p. № 179. URL: ttps://www.kmu.gov.ua/npas/ pro-zatverdzhennya-nacionalnoyi-eko-a179 (дата звернення 21.10.2021).

16. Про схвалення Концепції розвитку цифрових компетентностей та затвердження плану заходів з їі реалізації : Розпорядження Кабінету Міністрів України від23 березня 2021 р. № 167-p.URL:https://zakon.rada.gov.ua/laws/show/167-2021-p\# Text (дата звернення 21.10.2021).

\section{REFERENCES:}

1. World Bank Group (2016). World Development Report 2016: Digital Dividends. Washington, DC: World Bank. 330 p.

2. Dahlman, C., Mealy, S. \& Wermelinger, M. (2016). Harnessing the digital economy for developing countries. OECD Development Centre Working Papers. OECD Publishing. Paris, № 334.80 p.

3. UNCTAD. (2017). World Investment Report 2017: Investment and digital economy. Available at: https://unctad.org/en./publicationslibrary/wier2017_en / pdf. (accessed: 20.11.2021).

4. Baluieva, O.V., Chupryna, O.O. (2019). Metodychni osnovy modeliuvannia stratehichnykh priorytetiv sotsialno-ekonomichnoho rozvytku terytorii [Methodical bases of modeling of strategic priorities of social and economic development of territories]. Menedzher. Visnyk DonDUU. Seriia "Ekonomika", 4 (85), 23-30. DOI: 10.35340/2308-104X.2019.85-4-03. [in Ukrainian].

5. Bernaziuk, O. (2017). Rol ta mistse tsyfrovykh tekhnolohii u sferi publichnoho upravlinnia [The role and place of digital technologies in the field of public administration]. Informatsiine pravo, 10. Available at: http://pgp-journal.kiev.ua/ archive/2017/10/35.pdf (accessed: 17.11.2021). [in Ukrainian].

6. Valevskyi, O.L. (2001). Derzhavna polityka v Ukraini: metodolohiia analizu, stratehiia, mekhanizmy vprovadzhennia : monohrafia [Valevsky OL State policy in Ukraine: methodology of analysis, strategy, implementation mechanisms: a monograph]. Kyiv: NISD, 242 p. [in Ukrainian].

7. Kovbasiuk, Yu.V. etc. (2014). Derzhavna polityka : pidruchnyk [Public policy]. Kyiv : NADU, 448 p. [in Ukrainian].

8. Stepanov, V.Yu. (2014). Suchasni informatsiini tekhnolohii v derzhavnomu upravlinni [Modern information technology in public administration]. Ekonomika ta derzhava, 9, 101-105. Available at: http://www.economy.in. ua/pdf/9_2010/32.pdf (accessed: 01.11.2021). [in Ukrainian].

9. Shymanska, K.V., Bondarchuk,, V.V. (2021). Priorytetni napriamy ta mekhanizmy rozvytku tsyfrovoi ekonomiky v Ukraini [Priority directions and mechanisms of digital economy development in Ukraine]. Ekonomika, upravlinnia ta administruvannia, 1 (95), 17-22. [in Ukrainian]. 
10. Westerman, G., Bonnet, D. \& McAfee, A. (2014). Leading Digital: Turning Technology into Business Transformation. USA: Harvard Business School Publisher. 292 p.

11. Brynjolfsson, E. \& Kahin, B. (2002). Understanding the Digital Economy: Data, Tools, and Research [reprint]. USA: MIT Press. 407 p.

12. Evans, D. (2011). The Internet of Things: How the Next Evolution of the Internet Is Changing Everything. CISCO White Paper. Available at: . (accessed 21.10.2021).

13. Kornyeyeva, Yu.V. (2018). Rol derzhavy u spryyanni investyciyam u rozvytok cyfrovoyi ekonomiky [The role of the state in promoting investment in the digital economy]. Ekonomika prognozuvannya, 1, 120-134. [in Ukrainian].

14. Cabinet of Ministers of Ukraine. (2018). Pro skhvalennia Kontseptsii rozvytku tsyfrovoi ekonomiky ta suspilstva Ukrainy na 2018-2020 roky: Rozporiadzhennia Kabinetu Ministriv Ukrainy vid 17 sichnia 2018 r. № 67 [On approval of the Concept of development of the digital economy and society of Ukraine for 2018-2020: Order of 2018, January 17, № 67]. Ofitsiinyi visnyk Ukrainy, 16, 560. [in Ukrainian].

15. Cabinet of Ministers of Ukraine. (2021). Pro zatverdzhennia Natsionalnoi ekonomichnoi stratehii na period do 2030 r. : Postanova vid 03 bereznia 2021 № 179 [On approval of the National Economic Strategy for the period up to 2030: Resolution of 2021, March 3, № 179]. Available at: ttps://www.kmu.gov.ua/npas/ pro-zatverdzhennya-nacionalnoyi-eko-a179 (accessed 21.10.2021). [in Ukrainian].

16. Cabinet of Ministers of Ukraine. (2021). Pro skhvalennia Kontseptsii rozvytku tsyfrovykh kompetentnostei ta zatverdzhennia planu zakhodiv z yii realizatsii: Rozporiadzhennia Kabinetu Ministriv Ukrainy vid 23 bereznia 2021 № 167-r [On approval of the Concept of development of digital competencies and approval of the action plan for its implementation: Order of the Cabinet of Ministers of Ukraine dated 2021, March 03. № 167-r.]. Available at: https://zakon.rada.gov.ua/laws/show/167-2021-p\#Text (accessed 21.10.2021). 